\title{
FORMAS DE INGRESSO NOS CURSOS TÉCNICOS DE NÍVEL MÉDIO DA REDE FEDERAL DE ENSINO
}

(D) ALEX LARA MARTINS'

(D) ALFREDO COSTA"

\author{
Instituto Federal do Norte de Minas Gerais (IFNMG), Minas Gerais (MG), Brasil; \\ alexIm@bol.com.br \\ "Instituto Federal do Norte de Minas Gerais (IFNMG), Minas Gerais (MG), Brasil; \\ alfredo.costa@ifnmg.edu.br
}

\section{RESUMO}

O contexto da pandemia de covid-19 induziu as escolas a redefinirem os seus modelos pedagógicos. No caso da Rede Federal de Educação Profissional, houve a necessidade de se redefinirem, também, as formas de ingresso e os diferentes tipos de processo seletivo. Baseado nisso, este artigo apresenta a trajetória da educação profissional de nível médio no Brasil, focalizando os modos de ingresso e suas relações com o ambiente social e legal até 2019. Objetiva-se apresentar informações institucionais para se descreverem de modo sistemático as formas de admissão utilizadas até então. Os resultados da análise bibliográfica e dos diferentes sistemas de admissão poderão fornecer subsídios para a redefinição de políticas de acesso ao ensino profissionalizante de nível médio após o contexto da pandemia.

PALAVRAs-chave AdMISSÃo NA ESCOLA • ENSINO MÉdIO • CURSO TÉCNICO • COVID-19. 


\section{FORMAS DE INGRESO A LOS CURSOS TÉCNICOS DE NIVEL MEDIO DE LA RED FEDERAL DE EDUCACIÓN}

\section{RESUMEN}

El contexto de la pandemia de covid-19 indujo las escuelas a redefinir sus modelos pedagógicos. En el caso de la Rede Federal de Educação Profissional [Red Federal de Educación Profesional], fue necesario redefinir igualmente las formas de ingreso y los distintos tipos de proceso selectivo. En base a eso, el presente artículo presenta la trayectoria de la educación profesional de nivel medio en Brasil, enfocando los modos de ingreso y sus relaciones con el ambiente social y legal hasta 2019. Se pretendía presentar informaciones institucionales para describir de modo sistemático las formas de admisión utilizadas hasta entonces. Los resultados del análisis bibliográfico y de los diferentes sistemas de admisión podrán suministrar subsidios para redefinir políticas de acceso a la enseñanza profesionalizante de nivel medio después de la pandemia.

PALABRAS CLAVE ADMISIÓN EN LA ESCUELA • EDUCACIÓN MEDIA • CURSO TÉCNICO • COVID-19.

\section{ADMISSION PROCESSES TO HIGH SCHOOL TECHNICAL COURSES IN THE BRAZILIAN FEDERAL BASIC EDUCATION NETWORK}

\section{ABSTRACT}

The context of the Covid-19 pandemic has led schools to redefine their pedagogical models. In the case of the Rede Federal de Educação Profissional [Brazilian Federal Network for Professional Education], it was also necessary to redefine the admission processes and the different types of the selection process. Based on that, the present article shows the trajectory of secondary level professional education in Brazil, focusing on the types of admission processes and their relationships to the social and legal environment until 2019. The aim is to present institutional information to describe, systematically, the admission policies adopted until then. The results of the bibliographic analysis and the various formats of admission systems nowadays may provide support for the redefinition of the admissions policies for access to secondary level professional education after the pandemic situation.

KEYWORDS ADMISSION PROCESS • HIGH SCHOOL • TECHNICAL COURSE • COVID-19. 


\section{INTRODUÇÃO}

Um dos primeiros desafios para os gestores da área de educação, quando iniciam a concepção de seus projetos político-pedagógicos, é a especificação do perfil do estudante que ingressa na escola. O diagnóstico inicial deve estar em consonância tanto com os planos de permanência e êxito quanto com os arranjos produtivos e culturais locais e com o próprio perfil do egresso que se pretende educar. Estar em consonância remete à responsabilidade da instituição escolar de oferecer as condições específicas para diferentes trajetórias estudantis, cujos contextos sociais podem se assemelhar e cujas terminalidades variam entre assumir uma posição no mundo do trabalho e continuar os estudos formais em nível superior.

De modo geral, realiza-se a admissão de estudantes nas escolas das redes públicas municipais e estaduais pelo critério de zoneamento, em verdade, aloca-se um estudante em vez de admiti-lo conforme a consonância referida entre a escola, o perfil do egresso e a comunidade. As exceções são a rede de colégios militares, que usam tanto o vestibular quanto um sistema de admissão de filhos de militares, e a Rede Federal de Ensino Técnico e Tecnológico, responsável por apenas 0,9\% das matrículas na educação básica (BRASIL, 2021b), mas cujos índices de eficiência e qualidade atraem cada vez mais jovens. O crescimento de cerca de $30 \%$ da oferta de matrículas em cursos técnicos integrados ao ensino médio nos últimos cinco anos (BRASIL, 2021b) não foi capaz de suprir a demanda existente, motivo pelo qual se realizam os processos seletivos.

Doze anos após a criação da Rede Federal, é preciso questionar se os seus processos de admissão são eficientes ao selecionar estudantes com a adequada base científica, as competências necessárias e a identificação com o curso técnico escolhido. Um processo seletivo inadequado pode trazer dificuldades na relação de ensino e aprendizagem, implicando o insucesso dos estudantes e a desmotivação dos docentes. Por outro lado, tem-se a impressão de que os processos seletivos realizados por meio de pequenos vestibulares, contendo questões de múltipla escolha, promovem, paradoxalmente, a exclusão social de grupos com histórico de fragilidades epistêmicas pregressas, o que torna a escola uma reprodutora e legitimadora das desigualdades sociais, econômicas e científicas.

A temática deste artigo envolve a reconstrução histórica das formas de ingresso e dos diversos modelos de processos seletivos da Rede Federal em relação à oferta própria de cursos técnicos de nível médio. Pretende-se, ainda, descrever quais foram as formas de admissão de estudantes dos cursos técnicos integrados ao ensino médio (EMI) em 2019, antes da crise sanitária causada pela pandemia de covid-19, avaliando o modo como as instituições da Rede Federal justificam as diferentes escolhas de seus processos seletivos, em geral, tomando por critérios os custos, os contextos sociais e a meritocracia. 
Em momentos de crise, é necessário refletir e reconfigurar os modelos clássicos de vestibulares e processos de seleção, que devem adequar-se de modo mais eficiente aos diferentes contextos regionais. Com as atuais restrições financeiras de gastos públicos estabelecidos pelo Decreto n. 9.741 (BRASIL, 2019a), agravadas pelas regras de contingenciamento de despesas para enfrentamento da pandemia de covid-19 regidas, entre outras, pela Lei Complementar n. 173 (BRASIL, 2020), o Poder Executivo Federal impeliu os seus órgãos, fundos e entidades a reorganizarem o fluxo de sua dotação orçamentária. Nesse contexto, algumas instituições de ensino estão reavaliando a eficácia e as formas de admissão de seus processos seletivos. Este trabalho indica algumas possibilidades de prover os recursos destinados ao processo de admissão do EMI dessas instituições.

Após estabelecer o referencial teórico acerca das possíveis concepções de avaliação na Rede Federal de Ensino, realizar-se-á, na segunda seção, uma pesquisa bibliográfica sobre a história da educação profissional no Brasil, focalizando os modos de ingresso e suas relações com o ambiente social e legal. A hipótese geral dessa seção afirma que a dualidade e os conflitos entre as modalidades de ensino médio e de ensino técnico ressoam nos diferentes tipos de processos de admissão das instituições federais. A terceira seção será dedicada às modificações estruturais dos processos seletivos concebidas pelos institutos federais na última década, em especial, no ano de 2019, por meio do recolhimento de informações via Portal da Transparência e nos sites institucionais.

Não existem, até onde se pôde verificar, estudos descritivos atualizados sobre os processos de admissão escolar na Rede Federal. Porto Junior, Del Pino e Amaral (2009), Coutinho e Melo (2010) e Schwartzman (2014) tratam a questão especificando os tipos de processo de admissão em algumas instituições da rede. Cunha (2005b, 2005c), Campello (2007) e Amorim (2013) tratam-na de modo genérico, sem identificar de maneira completa as mudanças nas formas de admissão até o presente. Apesar dessa lacuna, o esforço inicial para descrever as diversas formas de ingresso, para o nível médio, pode oferecer resultados por meio dos quais se estabeleçam as bases para as políticas públicas de oferta de vagas para todas as modalidades de cursos da Rede Federal.

\section{REFERENCIAL TEÓRICO}

A Rede Federal de Educação Profissional, Científica e Tecnológica é composta por 17 unidades do Centro Federal de Educação Tecnológica (Cefet), 593 unidades dos institutos federais, 23 escolas técnicas vinculadas a universidades, a Universidade Tecnológica Federal do Paraná e o Colégio Pedro II, que ofertam cursos de educação infantil, ensino fundamental I e II, ensino médio, técnico, tecnólogo, qualificação 
profissional, licenciatura, bacharelado, especialização, mestrado e doutorado em diversos eixos tecnológicos (BRASIL, 2019b).

De acordo com a Lei n. 11.892 (BRASIL, 2008), que instituiu a Rede Federal, as instituições integrantes do sistema educacional possuem "autonomia administrativa, patrimonial, financeira, didático-pedagógica e disciplinar" (art. $1^{\circ}$ ). A relativa autonomia também serve para definir a forma de ingresso dos estudantes, seja por meio de processo seletivo, vestibular, sorteio, análise de currículo, entrevista, prova de aptidão, chamada pública ou alguma combinação desses modelos. As condições gerais para a escolha do processo de admissão são os princípios da administração pública, definidos nos arts. 37 e 38 da Constituição Federal (BRASIL, 1988), quais sejam, a legalidade, a moralidade, a impessoalidade, a razoabilidade, a proporcionalidade, a publicidade, a eficiência e o interesse público. Além desses princípios gerais, a chamada Lei das Cotas (n. 12.711) (BRASIL, 2012) definiu a reserva de vagas com base nos seguintes critérios: origem escolar (escola pública), renda, composição étnico-racial, portadores de deficiência ou necessidades especiais.

A Rede Federal tem especificidades que a diferenciam das universidades, por exemplo, ao estabelecer as suas bases conceituais na educação profissional e tecnológica, em que o trabalho é um princípio educativo, e a politecnia e a integração entre o científico e o técnico são meios para a formação emancipadora e omnilateral (PACHECO, 2014). Apesar dessa diferença, a maior parte das instituições ainda emula a forma como as universidades, durante o século XX, selecionavam os seus estudantes: o vestibular com provas objetivas de múltipla escolha. As provas de vestibular são entendidas, tradicionalmente, como avaliações anteriores ao processo de ensino e aprendizagem, quando deveriam ser vistas como elementos centrais da análise de perfil individual, cognitivo, afetivo e profissional, por meio do qual se possam formular programas de permanência e êxito. Imagina-se que, após a aprovação, todos os estudantes iniciam o curso do ponto zero do conhecimento, e sua formação é avaliada em uma escala que pode chegar a cem para cada disciplina e em cada período letivo.

Pacheco $(2014,2020)$ chama a atenção para as possibilidades abertas pelo EMI no tocante aos seus processos avaliativos. O autor identifica os quatro princípios educativos dos institutos federais: o trabalho, a formação humana integral, a prática social como fonte de conhecimentos e a indissociabilidade entre ensino, pesquisa e extensão. Juntos, podem transformar os institutos federais na "[...] mais ousada e criativa política educacional já experimentada em nosso país” (PACHECO, 2020, p. 20), desde que se supere, acrescentamos, a instrumentalização das formações e do conhecimento, de que resulta o modelo avaliativo clássico.

A reestruturação dos processos avaliativos deve estar em conformidade com o desenvolvimento e a adoção de práticas pedagógicas que pressupõem uma 
aprendizagem significativa, incluindo-se os critérios avaliativos utilizados para a admissão de estudantes. Como modificar a realidade educativa de uma escola em que os critérios de admissão são dados por meio de uma prova com questões de múltipla escolha, que incentiva mais as capacidades cognitivas de memorização do que as competências e habilidades que integram aspectos teóricos, políticos, sociais, culturais e estéticos? No caso do EMI, acrescente-se a essa lista o aspecto profissional: por que reduzir o processo seletivo de cursos técnicos apenas ao teste de inteligências lógico-matemáticas e verbo-linguísticas?

Wachowicz (2014) considera um paradoxo da avaliação por aprendizagem a dificuldade em se utilizarem estratégias de ensino capazes de ser eficientes diante da multiplicidade de contextos educacionais. Existe um constante fluxo de informações e modelos pedagógicos sensíveis à individualização do aprendizado, o que pode incentivar a escola a formular estratégias focadas em cada aluno, de acordo com as suas necessidades. A dificuldade consiste em partir de um modelo pedagógico comum e tradicional, representado e iniciado pelo "vestibular", para lidar com realidades, contextos e aprendizados diferentes, para os quais se exige outro modelo escolar, que faça frente ao que Bourdieu e Passeron (1992) descreveram como escola reprodutora de desigualdades e legitimadora dos conflitos sociais do capitalismo. Para esses autores, a escola é uma instituição que transmite a cultura dominante, privilegiando alguns em detrimento dos demais, especialmente aqueles que não tiveram contato, desde o início de seu processo de socialização, com o capital cultural dominante. Por isso, eles não conseguem dominar os códigos valorizados pela escola, logo, o aprendizado se torna mais difícil e, por consequência, excludente.

O modo como a gestão escolar inclui e exclui estudantes do processo formativo se enquadra parcialmente na descrição de Bourdieu e Passeron (1992), na medida em que os processos avaliativos clássicos, sejam eles vestibulares, provas ou trabalhos em grupo, exigem um conjunto de capitais (econômicos, culturais, sociais) que são desigualmente distribuídos entre as famílias. Isso significa que os membros de cada grupo investirão os respectivos capitais de acordo com a probabilidade de êxito, fechando o círculo vicioso que contorna o insucesso dos processos de admissão, o insucesso dos processos avaliativos intraescolares e o insucesso da própria formação escolar.

De maneira diversa, os institutos federais possuem objetivos inclusivos. Espera-se que o egresso do EMI atue criticamente sobre as relações e interações do mundo do trabalho, entendendo-o tanto como realização humana quanto como prática econômica. De acordo com Saviani (1997), o ser humano é visto nessa dupla perspectiva, isto é, tanto como produtor de técnicas quanto como interventor da natureza e inventor de significados. Mas se o egresso desses cursos deve atuar em sua 
multiplicidade - científica, tecnológica, cultural, política, ética, ambiental, etc. -, por que os processos seletivos insistem em instrumentos de avaliação reducionistas? Os processos de admissão deveriam refletir, ao contrário, a missão e os objetivos gerais das instituições de ensino.

Em relação à Rede Federal, dois dos objetivos de implantação são: aproximar a escolarização e a profissionalização, e articulá-las a políticas de desenvolvimento nacional e regional (PACHECO; PEREIRA; DOMINGOS SOBRINHO, 2009). Por isso, a sua lei de criação, no art. $6^{\circ}$, expressa a finalidade de "[...] orientar sua oferta formativa em benefício da consolidação e fortalecimento dos arranjos produtivos, sociais e culturais locais, identificados com base no mapeamento das potencialidades de desenvolvimento socioeconômico e cultural” (BRASIL, 2008).

Daí a necessidade de elaboração e acompanhamento dos planos de permanência e êxito. As ações afirmativas e os programas de apoio à admissão e ao êxito dos discentes estão sendo instituídos como forma de se garantir a dimensão socioeconômica, oportunizando aos estudantes de escolas públicas, em geral com menos privilégios sociais e econômicos, o acesso ao ensino de maior qualidade.

Silva e Veloso (2013) argumentam que o acesso à educação, regido pelo princípio constitucional de igualdade de oportunidades, deve levar em consideração tanto a permanência, cujos indicadores de qualidade são o número de matrículas, a taxa de diplomação e os programas de fixação do estudante, quanto a qualidade da formação, cujos índices são a organização acadêmica, a formação, titulação e dedicação do corpo docente, a participação discente/docente nas decisões, a escolha do curso, a avaliação institucional, a produção da pesquisa, a autonomia político-pedagógica e financeira, entre outros.

A Constituição de 1988 (BRASIL, 1988) reconheceu como foco de reparação e justiça social as desigualdades econômicas, raciais e geográficas historicamente consolidadas no país. Eis o fundamento constitucional para a Lei de Cotas, necessária, mas insuficiente para reparar todas as desigualdades educacionais do país. A atenção ao processo de admissão pode auxiliar nessa tarefa. Haj, Geanta e Orr (2018) argumentam que, considerando os sistemas de admissão do ensino superior europeu, é possível correlacionar o tipo de processo de admissão com o impacto social do curso, a taxa de inclusão social e o sucesso dos estudantes. Os autores desse estudo recomendam modificar os sistemas de admissão ainda no ensino médio, com práticas e critérios avaliativos diferentes dos vestibulares clássicos. Essa modificação torna coerente a adoção de práticas pedagógicas durante o processo de ensino e aprendizagem, que estimulam a autonomia, o potencial crítico e as múltiplas inteligências dos estudantes. 


\section{OS PROCESSOS DE ADMISSÃO NA REDE FEDERAL DO EMI (1909-2019)}

Esta seção objetiva apresentar um breve histórico das formas de ingresso e as modificações nos critérios de admissão de estudantes no ensino médio/técnico no Brasil desde 1909, indicando e comparando, quando possível, as respectivas vantagens e as desvantagens com o contexto histórico e regional.

Os projetos pedagógicos de um país participam do contexto social e político de sua época. As políticas educacionais e as concepções pedagógicas estão alinhadas, de um lado, a forças ideológicas e a um tipo de racionalidade; de outro lado, a relações de poder e às suas repercussões na vida cotidiana. No Brasil, os modelos de aprendizagem de ofícios estiveram a reboque da própria divisão social do trabalho. Até o último quartel do século XIX, parte significativa do trabalho orientado à manufatura e ao artesanato era realizada por mão de obra escravizada. Do ponto de vista axiológico, o trabalho do artífice e do operário possuía um aspecto negativo: homens livres marcavam a sua diferença porque tinham a posse de quem trabalhava ou tinham quem trabalhasse para eles. Do ponto de vista da organização sociopolítica, o ensino de ofícios e o incentivo ao trabalho manual representaram formas de manter a ordem, estabelecendo diretrizes centrais que orientassem um tipo de educação para as classes populares e outro para as elites (BRANDÃO, 1999; CUNHA, 2005a).

Entre as décadas de 1910 e 1930, as Escolas de Aprendizes Artífices foram configuradas para admitir, de modo assistencialista, os "desfavorecidos da fortuna", isto é, aqueles sem condições técnicas e preparo intelectual que, de outro modo, poderiam embaraçar o desenvolvimento do país (AMORIM, 2013, p. 32). De acordo com Fonseca (1962, p. 164), tratou-se de uma política cujo objetivo era a "dignificação da pobreza". Admitiam-se estudantes de ambos os sexos, pobres e de ascendência proletária, com idade entre 10 e 16 anos, para ensino de ofícios diferenciados mais um curso prático e básico de Ciências. Numa primeira fase, os internatos de ensino profissional selecionavam "menores desamparados" não viciados nem insubordinados (Quadro 1).

Implementou-se, inicialmente, uma pedagogia corretiva de dimensões nacionais, que não conseguia suprir a quantidade de operários necessários para as respectivas regiões. Por isso, a partir de 1926, estabeleceu-se, com base na Consolidação dos dispositivos concernentes às Escolas de Aprendizes Artifices, ${ }^{1}$ um currículo único, mais adequado aos propósitos de industrialização. Para efetuar a matrícula, bastava que os responsáveis dos "desfavorecidos da fortuna" a requeressem à secretaria escolar, no prazo adequado (FONSECA, 1961, p. 229), excetuando-se os candidatos com doenças infecciosas e portadores de deficiências físicas que os inabilitassem para o ofício. 

QUADRO 1 - Formas de admissão da Rede Federal de Ensino no Brasil na primeira metade
do século XX

\begin{tabular}{|c|c|c|c|c|c|}
\hline LEGISLAÇÃO & GOVERNO & MODELO & OBJETIVO & CONTEXTO & $\begin{array}{l}\text { FORMA DE } \\
\text { ADMISSÃO }\end{array}$ \\
\hline $\begin{array}{l}\text { Decreto n. } \\
7.566 / 1909 \\
\text { Consolidação } \\
(1926)\end{array}$ & $\begin{array}{l}\text { Nilo } \\
\text { Peçanha }\end{array}$ & $\begin{array}{l}\text { Escolas de } \\
\text { Aprendizes } \\
\text { Artífices }\end{array}$ & $\begin{array}{l}\text { Preparo técnico } \\
\text { e intelectual dos } \\
\text { "desfavorecidos da } \\
\text { fortuna", isto é, as classes } \\
\text { proletárias, para afastá-los } \\
\text { "da ociosidade ignorante, } \\
\text { escola do vício e do crime" } \\
\text { (BRASIL, 1909). }\end{array}$ & $\begin{array}{l}\text { Domínio do modelo } \\
\text { agrário-exportador e } \\
\text { industrialismo incipiente. } \\
\text { Coronelismo. }\end{array}$ & $\begin{array}{l}\text { Classe social } \\
\text { - proletariado, } \\
\text { Requerimento } \\
\text { dos pais, } \\
\text { Aptidão física, } \\
\text { Vocacional. }\end{array}$ \\
\hline $\begin{array}{l}\text { Decreto-lei } \\
\text { n. } 4.078 \\
\text { (BRASIL, } \\
1942 a)\end{array}$ & $\begin{array}{l}\text { Getúlio } \\
\text { Vargas }\end{array}$ & $\begin{array}{l}\text { Escolas } \\
\text { Industriais } \\
\text { e Técnicas } \\
\text { (Serviço } \\
\text { Nacional de } \\
\text { Aprendizagem } \\
\text { Industrial - } \\
\text { Senai, Training } \\
\text { within Industry) }\end{array}$ & $\begin{array}{l}\text { Formação profissional } \\
\text { equivalente ao secundário, } \\
\text { em especial para atender } \\
\text { ao trabalho industrial, com } \\
\text { vistas ao desenvolvimento } \\
\text { nacional. Criação do } \\
\text { Sistema S. }\end{array}$ & $\begin{array}{l}\text { Reposicionamento } \\
\text { do país dentro } \\
\text { do capitalismo } \\
\text { internacional, com } \\
\text { substituição de } \\
\text { importação por } \\
\text { manufaturados locais. } \\
\text { Corporativismo } \\
\text { estatal na promoção } \\
\text { do desenvolvimento } \\
\text { econômico. }\end{array}$ & $\begin{array}{l}\text { Exames de } \\
\text { admissão, } \\
\text { Aptidão } \\
\text { física, Aptidão } \\
\text { mental, } \\
\text { Conclusão do } \\
\text { curso primário, } \\
\text { Exame } \\
\text { intermediário. }\end{array}$ \\
\hline
\end{tabular}

Fonte: Elaboração dos autores.

Desde o tempo da Colônia, o ensino artesanal e manufatureiro destinava-se aos miseráveis e delinquentes, que deviam se ocupar de funções similares às dos escravizados. Mesmo após a "Consolidação" (FONSECA, 1961), o ensino profissional resumia-se à formação para trabalhos manuais e, quando muito, manufatureiros (BRANDÃO, 1999). Entre as décadas de 1920 e 1930, observou-se uma mudança no perfil dos ingressantes no ensino profissional. Com a demanda por mão de obra local especializada, a negatividade conferida ao trabalho foi transvalorada ideologicamente, de forma que o trabalho passou a ser um fator de dignidade, não apenas para órfãos e desvalidos da sorte, mas para pessoas dotadas de qualidades e aptidões com as quais pudessem ascender socialmente. Assim, as aptidões físicas, intelectuais e vocacionais tornaram-se critérios de seleção para o ensino profissionalizante.

A transformação das Escolas de Aprendizes Artífices em Escolas Industriais, de nível pós-primário, por meio de lei orgânica de 1942, buscou resolver algumas dificuldades, como a baixa taxa de matrícula dos cursos noturnos, o baixo rendimento dos estudantes e as altas taxas de evasão (CUNHA, 2005b).

De acordo com Cunha (2005c), as leis orgânicas entre 1942 e 1946 organizaram o ensino profissionalizante industrial como um sistema que articulava cursos industriais, destinados à formação de menores para o mercado de trabalho, e cursos de aprendizagem industrial, destinados aos aprendizes dos estabelecimentos industriais. $\mathrm{O}$ ensino profissional foi deslocado para o grau médio, dividindo espaço com o ensino secundário ginasial, exclusivo para "as individualidades condutoras" da nação, conforme expressão do Decreto-lei n. 4.244 (BRASIL, 1942b). Assim, os cursos profissionalizantes passaram a selecionar estudantes com menor defasagem 
de aprendizado, diretamente da rede de escolas primárias, com "[...] a realização de exames vestibulares e testes de aptidão física e mental" (CUNHA, 2005c, p. 36). Ainda que inusitada, essa foi a primeira tentativa de diluir a dicotomia entre as diferenças qualitativas de ensino dos tipos de formação secundária, embora se produzisse, como efeito colateral, uma divisão interna entre os beneficiários do ensino industrial (jovens empregados e desempregados). Contudo, a seleção mais criteriosa de estudantes não foi suficiente para reverter a situação do ensino técnico, principalmente porque ele não dava acesso direto a cursos superiores, sendo insuficiente para a almejada possibilidade de ascensão social.

No decorrer da década de 1940, cresceu a implementação de cursos técnicos industriais em virtude do projeto industrializante do país, que teve como marco a criação da Companhia Siderúrgica Nacional; além da demanda produtiva decorrente da Segunda Guerra e da paulatina substituição da antiga mão de obra estrangeira de alta qualificação pelo crescente contingente de técnicos e bacharéis formados no Brasil. Havia também a pressão interna de estudantes e egressos pelo reconhecimento e pela articulação dos cursos industriais no sistema oficial de ensino. As leis orgânicas dessa década estipulavam que o egresso do ensino primário poderia cursar (1) o secundário ginasial; (2) o $1^{\circ}$ ciclo do curso normal (formação de professores); (3) os cursos de aprendizagem profissional nos ramos industrial, comercial ou agrícola (Figura 1). Após a aprovação no ciclo básico do ensino médio, os egressos do curso ginasial poderiam matricular-se em qualquer curso do $2^{\circ}$ ciclo (técnico), posteriormente à verificação de capacidade mental e física para os trabalhos do curso acrescida de exame vestibular. Os demais eram obrigados a continuar os estudos na mesma área. Após verificados os mesmos critérios, eles só poderiam acessar cursos superiores que fossem diretamente relacionados com a sua área de formação técnica. 
FIGURA 1 - Articulação entre os níveis de ensino segundo as "leis orgânicas", 1942-1946

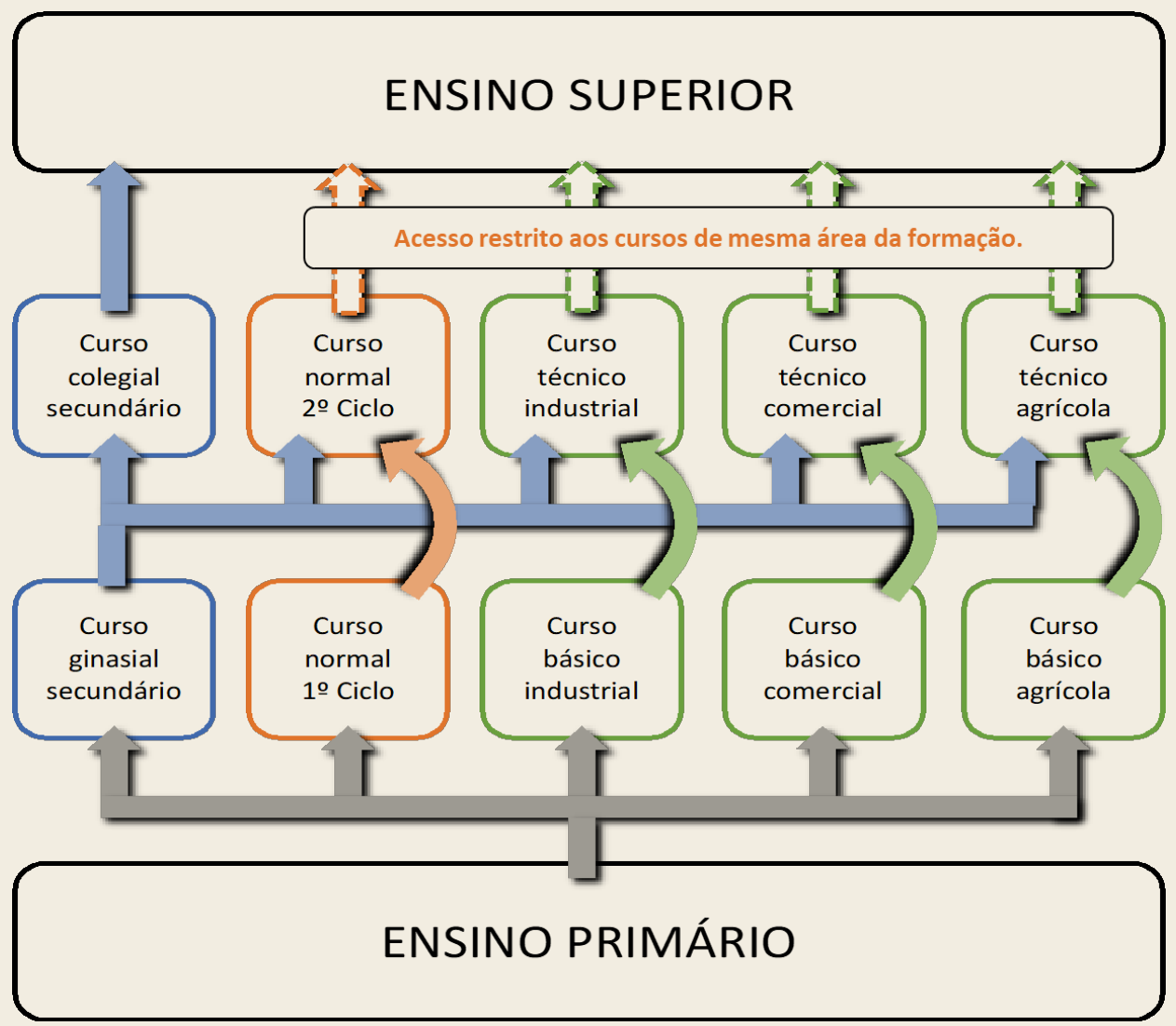

Fonte: Adaptada de Cunha (2005c, p. 39).

A seleção mais criteriosa de egressos do ensino primário acrescida do processo seletivo intermediário foram fatores decisivos para o início da elitização do ensino técnico brasileiro. Após a conclusão do primeiro ciclo do ensino industrial, com disciplinas de caráter pré-profissional, cujos conteúdos versavam sobre cultura geral e trabalhos manuais, parte significativa dos estudantes dirigiam-se ao mercado de trabalho, atuando como artífices ou operários. De acordo com José Augusto Dias (1967² apud CUNHA, 2005c), 3/4 dos estudantes no $2^{\circ}$ ciclo do ensino técnico eram compostos por ginasianos, de origem socioeconômica mais elevada do que os alunos do industrial, aos quais se impunha a necessidade de trabalho imediato para sustento familiar em paralelo à possibilidade de ascensão social oportunizada pela conclusão do curso secundário. Essa possibilidade não foi atualizada de modo significativo, mesmo após a revogação da necessidade de exames vestibulares entre os ciclos (Lei n. 3.552/1959), em grande medida devido à pressão das corporações profissionais de nível superior, como os Conselhos de Engenharia e Arquitetura, que atuaram para reservar para os seus pares os segmentos de trabalho mais bem remunerados. 
A reconfiguração do sistema de ensino técnico a partir da década de 1950 contribuiu decisivamente para que os exames vestibulares se tornassem a forma preeminente de ingresso nos cursos. Inicialmente, os exames foram concebidos para ratificar a equivalência entre áreas e níveis ou a passagem entre os ciclos "ginasial" e "colegial". De um lado, o Senai e seus congêneres assumiram a hegemonia dos cursos de aprendizagem profissional, pressionando para que os concluintes desses cursos pudessem ingressar no curso básico industrial, na série compatível com o seu rendimento aferido por um exame vestibular. Por outro lado, os cursos técnicos e industriais buscaram se reestruturar para fazer frente às novas transformações econômicas, ofertando disciplinas propedêuticas no primeiro ciclo e disciplinas de orientação vocacional ligadas à formação de artífices no segundo ciclo. Assim, a Lei n. 1.076 (BRASIL, 1950) assegurou aos egressos dos cursos industriais básicos a matrícula em qualquer área do segundo ciclo, bastando prestar "[...] exames de complementação" das disciplinas não estudadas. Ademais, os diplomados nos cursos técnicos poderiam, então, prestar exame vestibular para cursos superiores, observada a restrição do art. $5^{\circ}$ do Decreto n. 34.330 (BRASIL, 1953).

O modelo de admissão dos ginásios vocacionais-industriais de São Paulo, fortemente ligados ao Sistema S, envolveu, a partir de 1967, a proposta de exame de vestibular unificado como "[...] medida de democratização do ensino público" (CUNHA, 2005c, p. 169). Ora, o projeto de universalização da educação e unificação curricular do sistema educacional estava posto desde a primeira Lei de Diretrizes e Bases da Educação Nacional (LDB), Lei n. 4.024, cujo art. 36 estabelece que:

O ingresso na primeira série do $1^{\circ}$ ciclo dos cursos de ensino médio de-
pende de aprovação em exame de admissão, em que fique demonstra-
da satisfatória educação primária, desde que o educando tenha onze
anos completos ou venha a alcançar essa idade no correr do ano letivo.
(BRASIL, 1961)

O fracasso das reformas do ensino técnico a partir da década de 1960 gerou três consequências importantes: as novas escolas, reformadas para o ensino vocacional e com o corpo docente qualificado, foram cada vez mais ocupadas por estudantes da classe média alta, que tinham a privilegiada base escolar pregressa e, então, enxergavam o ensino médio profissionalizante como trampolim igualmente privilegiado para acessar o ensino superior. Além disso, a sondagem vocacional, restrita à iniciação a trabalhos manuais, estava defasada em relação à nova realidade do mercado tecnológico e industrial a partir da década de 1970, que exigia mais do que torneiros e marceneiros (CUNHA, 2005c). Por fim, a universalização compulsória do ensino profissionalizante e a subordinação do currículo de $2^{\circ}$ grau ao profissional, expressas pela nova LDB - Lei n. 5.692 (BRASIL, 1971) -, sobrecarregaram as escolas 
técnicas industriais da Rede Federal, dada a falta de estrutura e a incompetência das administrações estaduais de ensino. No plano das ideias, extinguiram-se os processos de admissão aos cursos técnicos, então universalizados compulsoriamente (Quadro 2). No plano prático, as reformas agravaram a dualidade entre os tipos de formação (geral e profissional) e entre a destinação da oferta de ensino, privilegiando as classes economicamente abastadas, vale dizer, de um público "[...] branco, masculino, urbano-industrial, presente na oferta tradicional de formação profissional” (CUNHA, 2005c, p. 238).

\section{QUADRO 2 - Formas de admissão da Rede Federal de Ensino no Brasil na segunda metade do século $X X$}

\begin{tabular}{|c|c|c|c|c|c|}
\hline LEGISLAÇÃO & GOVERNO & MODELO & OBJETIVO & CONTEXTO & $\begin{array}{l}\text { FORMA DE } \\
\text { ADMISSÃO }\end{array}$ \\
\hline $\begin{array}{l}\text { Lei n. } 3.552 \\
\text { (BRASIL, } \\
\text { 1959) }\end{array}$ & $\begin{array}{l}\text { Juscelino } \\
\text { Kubitschek }\end{array}$ & $\begin{array}{l}\text { Escolas } \\
\text { Técnicas } \\
\text { Federais } \\
\text { (autarquia) }\end{array}$ & $\begin{array}{l}\text { Formação técnica de melhor } \\
\text { qualidade, com vistas a } \\
\text { suprir necessidades de } \\
\text { infraestruturas locais e } \\
\text { regionais. Autonomia das } \\
\text { escolas técnicas federais. }\end{array}$ & $\begin{array}{l}\text { Aprofundamento } \\
\text { da relação entre o } \\
\text { Estado e a economia. }\end{array}$ & $\begin{array}{l}\text { Exames } \\
\text { vestibulares e de } \\
\text { complementação. }\end{array}$ \\
\hline $\begin{array}{l}\text { Decreto } \\
\text { n. } 53.041 \\
\text { (BRASIL, } \\
1963 \text { ) }\end{array}$ & $\begin{array}{l}\text { João } \\
\text { Goulart }\end{array}$ & $\begin{array}{l}\text { Programa } \\
\text { Intensivo de } \\
\text { Preparação } \\
\text { de Mão- } \\
\text {-de-Obra } \\
\text { (PIPMO) }\end{array}$ & $\begin{array}{l}\text { Criação do PIPMO, com } \\
\text { treinamento acelerado } \\
\text { para setores da indústria, } \\
\text { agricultura e serviços. } \\
\text { Consolidação do Sistema S. } \\
\text { Após 1964, o modelo passou } \\
\text { a conceder incentivos fiscais a } \\
\text { empresas para capacitação. }\end{array}$ & $\begin{array}{l}\text { Discussão sobre as } \\
\text { reformas de base } \\
\text { (agrária, tributária, } \\
\text { educacional, etc.), } \\
\text { posicionamento } \\
\text { fluido do país } \\
\text { nas relações } \\
\text { internacionais } \\
\text { (Guerra Fria). }\end{array}$ & $\begin{array}{l}\text { Exames de } \\
\text { admissão para } \\
\text { maiores de } 11 \\
\text { anos. }\end{array}$ \\
\hline $\begin{array}{l}\text { Lei n. } 6.545 \\
\text { (BRASIL, } \\
\text { 1978) }\end{array}$ & $\begin{array}{l}\text { Ernesto } \\
\text { Geisel }\end{array}$ & $\begin{array}{l}\text { Cefets e } \\
\text { Sistema S }\end{array}$ & $\begin{array}{l}\text { Experiência inicial de Cefets } \\
\text { nos estados do Paraná, } \\
\text { Minas Gerais e Rio de Janeiro, } \\
\text { para formar engenheiros } \\
\text { de operação e tecnólogos. } \\
\text { "Cefetização" das Escolas } \\
\text { Técnicas e priorização } \\
\text { dos cursos superiores de } \\
\text { tecnologia. }\end{array}$ & $\begin{array}{l}\text { Ditadura militar, } \\
\text { "é necessário } \\
\text { formar técnicos } \\
\text { sob o regime da } \\
\text { urgência" (BRASIL, } \\
\text { 2009). Expansão do } \\
\text { corporativismo para } \\
\text { atender às demandas } \\
\text { de flexibilização do } \\
\text { mercado de trabalho. }\end{array}$ & $\begin{array}{l}\text { Exames } \\
\text { vestibulares } \\
\text { (ampla } \\
\text { concorrência) e } \\
\text { ações afirmativas } \\
\text { (Pró-Técnico). }\end{array}$ \\
\hline $\begin{array}{l}\text { Decreto } \\
\text { n. } 2.208 \\
\text { (BRASIL, } \\
1997 a)\end{array}$ & $\begin{array}{l}\text { Fernando } \\
\text { Henrique } \\
\text { Cardoso }\end{array}$ & $\begin{array}{l}\text { Plano } \\
\text { Nacional de } \\
\text { Qualificação } \\
\text { do } \\
\text { Trabalhador } \\
\text { (Planfor). } \\
\text { Nova LDB }\end{array}$ & $\begin{array}{l}\text { Reforço da dualidade } \\
\text { entre ensino propedêutico } \\
\text { (acadêmico) e profissional, } \\
\text { flexibilização dos currículos } \\
\text { e dos cursos conforme as } \\
\text { demandas especializadas } \\
\text { do mercado, e autonomia } \\
\text { das instituições de ensino. } \\
\text { "Senaização" das Escolas } \\
\text { Técnicas. }\end{array}$ & $\begin{array}{l}\text { Processos de } \\
\text { privatização de } \\
\text { empresas estatais, } \\
\text { estabilização } \\
\text { monetária e } \\
\text { introdução de } \\
\text { programas de } \\
\text { transferência de } \\
\text { renda. }\end{array}$ & $\begin{array}{l}\text { Exames } \\
\text { vestibulares } \\
\text { (ampla } \\
\text { concorrência) e } \\
\text { ações afirmativas } \\
\text { (Pró-Técnico). }\end{array}$ \\
\hline
\end{tabular}

Fonte: Elaboração dos autores.

De modo concomitante à reorientação dessas reformas, ocorreu a "cefetização" das escolas técnicas, termo que designa o espaço destinado às escolas federais no Plano Nacional de Qualificação do Trabalhador (Planfor). Houve o deslocamento do nível de atuação das escolas técnicas profissionais "para cima”, isto é, elas passaram 
a atuar nos níveis pós-médio e superior, com a oferta de cursos superiores de curta duração (tecnólogos), visando a suprir as necessidades do mercado de trabalho não supridas pelo $2^{\circ}$ grau profissionalizante, de cursos superiores normais, especialmente na área de engenharia, e de cursos de pós-graduação (CAMPELLO, 2007).

$\mathrm{O}$ acirramento da concorrência por vagas em cursos técnicos de nível médio da Rede Federal implicou a remodelagem dos exames de admissão, agora espelhados nos exames vestibulares das universidades, emuladas pelos novos Cefets de Minas Gerais, Paraná e Rio de Janeiro. De acordo com Coutinho e Melo (2010), essas instituições buscaram mitigar o processo de exclusão social via escolarização, promovido pelos pequenos vestibulares, ao criar os cursos Pró-Técnicos (PT), cujo objetivo era "[...] melhorar o nível de conhecimento dos alunos provenientes de escolas públicas, habilitando-os a competir pelas vagas oferecidas pelas escolas da rede federal" (COUTINHO; MELO, 2010, p. 24). A ideia era criar cursos de nivelamento, com a seleção de conteúdos coincidentes com o tipo de questão cobrada nos processos seletivos.

Além da prova objetiva de ampla concorrência, cada uma das instituições de ensino dessa rede, cujo conselho gestor era dotado de relativa autonomia administrativa (Lei n. 6.545, art. $3^{\circ}$ ) (BRASIL, 1978), passou a definir ações afirmativas para acesso a seus cursos. No Cefet-MG, por exemplo, o processo seletivo ao PT, a partir de 1979, ocorria por meio de avaliação do histórico escolar do ensino fundamental, sendo a admissão no curso técnico condicionada à avaliação processual e ao controle de frequência (COUTINHO; MELO, 2010). Ações inclusivas esporádicas foram seguidas por outras instituições da Rede: até o fim dos anos 1980, a Escola Técnica Federal de Pelotas-RS admitia no PT os excedentes do processo seletivo de ampla concorrência, com reserva de vagas para filhos de sindicalizados, sendo a admissão no curso técnico condicionada à aprovação no PT e no $1^{\circ}$ semestre regular, após o que os estudantes prestavam exame para classificação em uma habilitação técnica (PORTO JUNIOR; DEL PINO; AMARAL, 2009).

No início dos anos 1990, o Sistema Nacional de Educação Tecnológica, criado pela Lei n. 8.948 (BRASIL, 1994), procurou renovar o significado da "cefetização". As Escolas Técnicas Federais remanescentes, inclusive as Escolas Agrotécnicas, são transformadas em Cefets. A implementação do sistema, contudo, realizou-se apenas a partir de 1997, com a publicação dos decretos n. 2.208 (1997a) e n. 2.406 (BRASIL, 1997b). O primeiro definiu as características da educação profissional e da oferta dos cursos, separando da educação formal o ensino profissionalizante (art. $4^{\circ}$ ), cuja organização curricular deveria ser independente do ensino médio (art. $5^{\circ}$ ). Consolidou-se, na visão de Kuenzer (2011), a inversão de polos da dualidade estrutural da educação pública brasileira, tendo tornado positivo o polo axial do ensino profissionalizante restrito, cada vez mais almejado pela média e alta burguesia, e 
negativo o polo do ensino propedêutico universalizado, desqualificado e relegado às classes mais pobres, sob o pretexto da democratização.

Entre a promulgação da nova LDB - Lei n. 9.394 (BRASIL, 1996) - e a criação dos institutos federais - Lei n. 11.892 (BRASIL, 2008) -, a educação profissional permaneceu alheia às transformações legais e às propostas de reforma curricular que passaram a regulamentar o ensino médio, restando como diretrizes os curtos arts. 39 a 41 da LDB, que condicionava "[...] a matrícula à capacidade de aproveitamento e não necessariamente ao nível de escolaridade”, numa espécie de "senaização" das escolas técnicas federais. As causas para o relativo abandono ou apartamento do ensino técnico de nível médio na época, de acordo com Cunha (2005c), foram: os conflitos no campo educacional, entre progressistas defensores da politecnia como princípio educativo e defensores do sistema de aprendizagem controlados pelo patronato, cujo modelo era o Sistema S; o custo operacional das escolas técnicas da rede federal; a baixa quantidade de egressos atuantes em sua área de formação; e o caráter propedêutico assumido pelos currículos das escolas técnicas. Pode-se arrolar nessa lista a queda de braços entre a política ministerial do governo Fernando Henrique Cardoso e os quadros pedagógicos das escolas técnicas federais e dos Cefets sobre o tipo de oferta e o público atendido. Ainda de acordo com o autor, esses fatores evidenciaram o "grave problema" dos processos de admissão dessas escolas.

O cenário mudou nos anos iniciais do século XXI, com a política educacional de ampliação dos espaços formativos e de universalização do ensino básico, inclusive do ensino médio (Quadro 3). Prova disso é o Decreto n. 5.478 (BRASIL, 2005b), que instituiu $10 \%$ do total de vagas de ingresso na educação profissional técnica de nível médio para jovens e adultos fora da idade escolar. Essa mudança de rumo, que culminará na lei de criação dos institutos federais, refletiu uma mudança de concepção pedagógica sobre a integração entre cursos técnicos e ensino médio. A consolidação desse projeto inclusivo de redução das desigualdades sociais pode ser vista no público a que se destinam os institutos federais e na forma diversificada como eles instituem os seus processos de admissão atualmente. Após longo debate e diversas tentativas de formular políticas públicas educacionais que fizessem frente a essas desigualdades, o governo federal instituiu a Lei n. 12.711 (BRASIL, 2012). No caso do ensino médio, essa lei estabelece que as instituições federais devem reservar metade das suas vagas para estudantes que cursaram integralmente o ensino fundamental em escolas públicas. Destes, metade das vagas deve ser reservada para estudantes oriundos de famílias com renda per capita igual ou inferior a 1,5 salário mínimo. Em todo caso, essas vagas são preenchidas por autodeclarados pardos, pretos, indígenas e pessoas com deficiência, de acordo com a proporção verificada no último censo do Instituto Brasileiro de Geografia e Estatística. 


\section{QUADRO 3 - Formas de admissão da Rede Federal de Ensino no Brasil no início do século XXI}

\begin{tabular}{|l|l|l|l|l|l|}
\hline LEGISLAÇÃO & GOVERNO & \multicolumn{1}{|c|}{ MODELO } & \multicolumn{1}{|c|}{ OBJETIVO } & \multicolumn{1}{c|}{ CONTEXTO } & \multicolumn{1}{c|}{$\begin{array}{c}\text { FORMA DE } \\
\text { ADMISSÃO }\end{array}$} \\
\hline $\begin{array}{l}\text { Lei } n .11 .892 \\
\text { (BRASIL, } \\
\text { 2008) }\end{array}$ & $\begin{array}{l}\text { Luiz Inácio } \\
\text { Lula da } \\
\text { Silva }\end{array}$ & $\begin{array}{l}\text { Rede Federal } \\
\text { de Educação } \\
\text { Profissional, } \\
\text { Científica e } \\
\text { Tecnológica }\end{array}$ & $\begin{array}{l}\text { Aproximar a escolarização } \\
\text { e a profissionalização, e } \\
\text { articulá-las com políticas } \\
\text { de desenvolvimento } \\
\text { nacional e regional. }\end{array}$ & $\begin{array}{l}\text { Governo marcado } \\
\text { pela articulação } \\
\text { e expansão dos } \\
\text { programas sociais. }\end{array}$ & $\begin{array}{l}\text { Exames } \\
\text { vestibulares (ampla } \\
\text { concorrência). }\end{array}$ \\
\hline $\begin{array}{l}\text { Lei n. 12.711 } \\
\text { (BRASIL, } \\
\text { 2012) }\end{array}$ & $\begin{array}{l}\text { Dilma } \\
\text { Rousseff }\end{array}$ & $\begin{array}{l}\text { Rede Federal } \\
\text { de Educação } \\
\text { Profissional, } \\
\text { Científica e } \\
\text { Tecnológica }\end{array}$ & $\begin{array}{l}\text { Ampliação, interiorização } \\
\text { e consolidação da Rede } \\
\text { com objetivos inclusivos e } \\
\text { de assistência social. }\end{array}$ & $\begin{array}{l}\text { Aumento significativo } \\
\text { de investimentos } \\
\text { em educação, } \\
\text { crises políticas e } \\
\text { econômicas. }\end{array}$ & $\begin{array}{l}\text { Exames } \\
\text { vestibulares, análise } \\
\text { de histórico, sorteio, } \\
\text { etc., com ações } \\
\text { afirmativas (cotas). }\end{array}$ \\
\hline
\end{tabular}

Fonte: Elaboração dos autores.

O Plano de Expansão da Rede Federal de Educação Tecnológica foi dividido em três fases. Em cada fase houve um modo predominante de admissão de estudantes. A primeira fase demonstrava a necessidade de se romper com os processos de "cefetização" e "senaização" que se impunham sobre a Rede Federal. A segunda fase esteve relacionada à necessidade de se construir uma identidade institucional para a Rede Federal, com alinhamento de conceitos e práticas da educação profissional e tecnológica. A terceira está relacionada à consolidação dessa identidade, cuja efetividade envolve, entre outras coisas, o acesso de estratos da sociedade que historicamente sofrem desvantagens educacionais.

Referida por Pacheco (2010) como uma "revolução", o projeto político-pedagógico de criação dos institutos federais é ambicioso e multifacetado, tanto em relação à oferta de cursos (de treinamento profissional a pós-graduação) quanto em relação aos objetivos (da difusão do conhecimento científico à justiça social). As ações afirmativas e os programas de apoio à admissão e ao êxito dos discentes foram instituídos como forma de garantir a dimensão socioeconômica, oportunizando aos estudantes de escolas públicas, em geral com menos privilégios econômicos, o acesso ao ensino de maior qualidade. Vale ressaltar, por fim, o esforço de alguns institutos federais em estabelecer políticas de ação afirmativa de acordo com o seu contexto socioeconômico, por exemplo, reservando vagas para egressos das Escolas Família Agrícola (Instituto Federal do Norte de Minas Gerais - IFNMG), quilombolas (Instituto Federal do Tocantins - IFTO), assentados da reforma agrária (Instituto Federal da Paraíba - IFPB), etc.

\section{PROCESSOS ATUAIS DE ADMISSÃO DA REDE FEDERAL DE EDUCAÇÃO}

A reestruturação dos processos avaliativos, em conformidade com o desenvolvimento e a adoção de práticas pedagógicas que pressupõem uma aprendizagem significativa, faz parte da organização escolar como um todo, incluindo os critérios 
avaliativos utilizados para a admissão de estudantes. Pretende-se aqui imprimir uma fotografia dos processos de admissão da Rede Federal em 2019, com os objetivos de identificar, registrar e analisar os fatores e os tipos de processo de admissão de estudantes na Rede Federal, de modo a orientar a ação de gestores para propostas de processos seletivos mais adequados para cada contexto educacional. A depender do tipo de proposta pedagógica e do perfil do egresso que se deseja educar, é possível selecionar as variáveis relevantes, discutidas e estabelecidas neste estudo, e formular um processo de admissão específico. Esse tipo de análise poderá fazer parte, em seguida, dos planos de permanência e êxito das instituições de ensino da Rede Federal. A base de dados foi formada pelas informações provenientes de três fontes:

- Plataforma Nilo Peçanha (BRASIL, 2019b): em que se identificaram as unidades de ensino, as vagas e os tipos de oferta da educação profissional, e a relação inscritos/vagas. Os microdados da Plataforma Nilo Peçanha foram tabulados com o software Tableau Public 2019.3 e convertidos para o formato *.xlsx. Os mapas foram elaborados com o software ArcGIS 10.

- Plataforma Integrada de Ouvidoria e Acesso à Informação (BRASIL, 2021a). Elaborou-se um questionário, enviado via Plataforma Integrada de cada órgão público, a ser respondido pelos gestores da Rede Federal de Educação. O questionário continha as seguintes questões: Quais foram as formas de admissão de estudantes nos cursos técnicos integrados ao ensino médio da instituição com início em 2019? Quais campi da instituição e quais cursos técnicos integrados ao ensino médio estabeleceram uma forma de ingresso diferente do processo seletivo contendo prova de múltipla escolha?

- Sites institucionais: em que foram acessados os editais dos processos seletivos de cada uma das instituições federais de ensino. Além do tipo de admissão adotado pelas instituições, os editais detalham o processo de seleção com informações, por exemplo, sobre a quantidade de questões e os conteúdos exigidos (no caso dos vestibulares), a forma de análise do histórico escolar, os procedimentos relacionados ao sorteio e às vagas remanescentes, etc.

\section{RESULTADOS}

Os resultados da pesquisa nas três fontes nos permitiram, em primeiro lugar, identificar e avaliar os diferentes tipos de admissão adotados. Além disso, pôde-se mapear e quantificar a distribuição dos modos de ingresso nas diferentes instituições espalhadas pelo país, bem como o total de vagas oferecidas (Tabela 1 e Figura 2). 
TABELA 1 - Tipos de processo de admissão por unidades da Rede Federal e vagas (2019)

\begin{tabular}{l|c|c}
\hline \multicolumn{1}{c|}{ TIPOS DE PROCESSO } & UNIDADES DA REDE & VAGAS OFERTADAS \\
\hline Sem processo & $11(1,8 \%)$ & $1.005(0,7 \%)$ \\
\hline Vestibular & $340(56,8 \%)$ & $86.597(57,2 \%)$ \\
\hline Vestibular e redação & $56(9,3 \%)$ & $12.823(8,5 \%)$ \\
\hline Vestibular e provas discursivas & $8(1,3 \%)$ & $1.919(1,3 \%)$ \\
\hline Análise de currículo & $135(22,5 \%)$ & $32.969(21,8 \%)$ \\
\hline Sorteio & $11(1,8 \%)$ & $5.173(3,4 \%)$ \\
\hline Vestibular / análise de currículo & $1(0,2 \%)$ & $258(0,2 \%)$ \\
\hline Vestibular / sorteio & $8(1,3 \%)$ & $1.656(1,1 \%)$ \\
\hline Vestibular / exame de aptidão & $2(0,3 \%)$ & $1.929(1,3 \%)$ \\
\hline Vestibular e redação / exame de aptidão & $8(1,3 \%)$ & $1.927(1,3 \%)$ \\
\hline Vestibular / entrevista / análise de currículo & $1(0,2 \%)$ & $185(0,1 \%)$ \\
\hline Vestibular / análise de currículo / chamada pública & $18(3 \%)$ & $5.042(3,3 \%)$ \\
\hline TOTAL & $\mathbf{5 9 9 ( 1 0 0 \% )}$ & $\mathbf{1 5 1 . 4 8 3}(\mathbf{1 0 0} \%)$ \\
\hline
\end{tabular}

Fonte: Elaboração dos autores. 
FIGURA 2 - Mapa de distribuição da Rede Federal por tipo de admissão (2019)

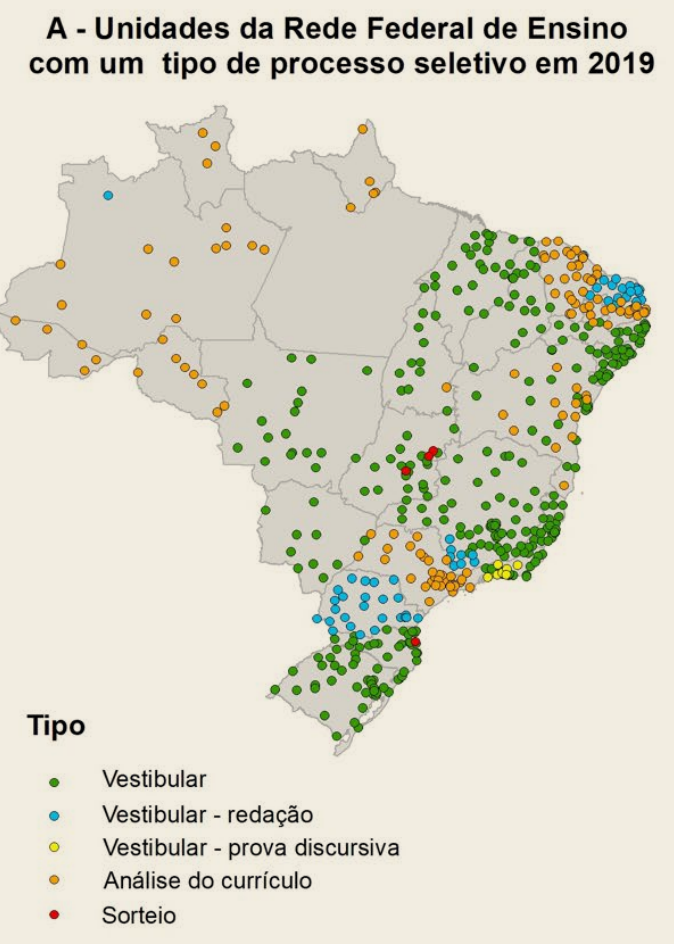

A - Unidades da Rede Federal de Ensino
B - Unidades da Rede Federal de Ensino com dois ou três tipos de processo seletivo em 2019

Tipo

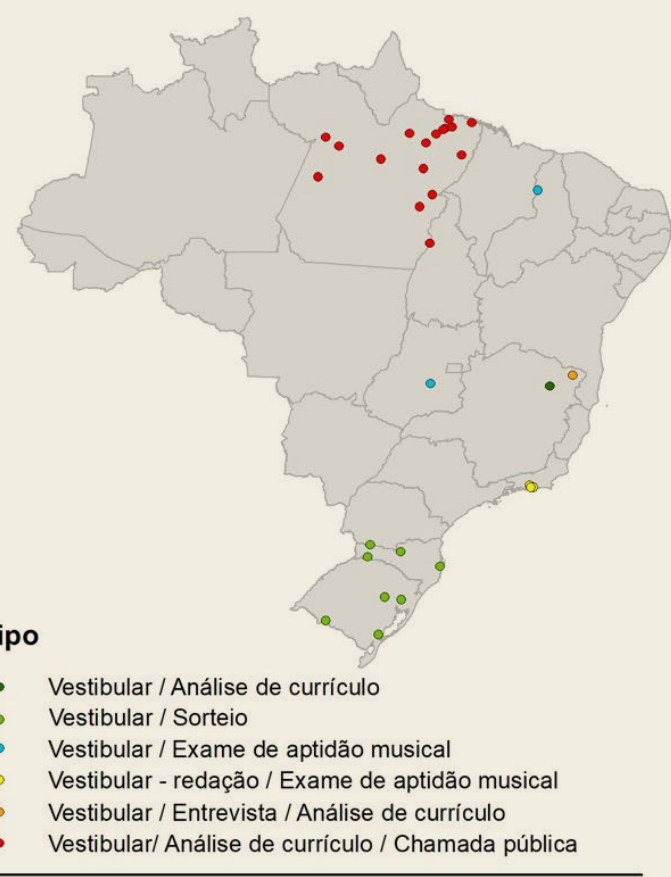

C - Unidades da Rede Federal de Ensino por quantidade total de vagas oferecidas em processos seletivos em 2019

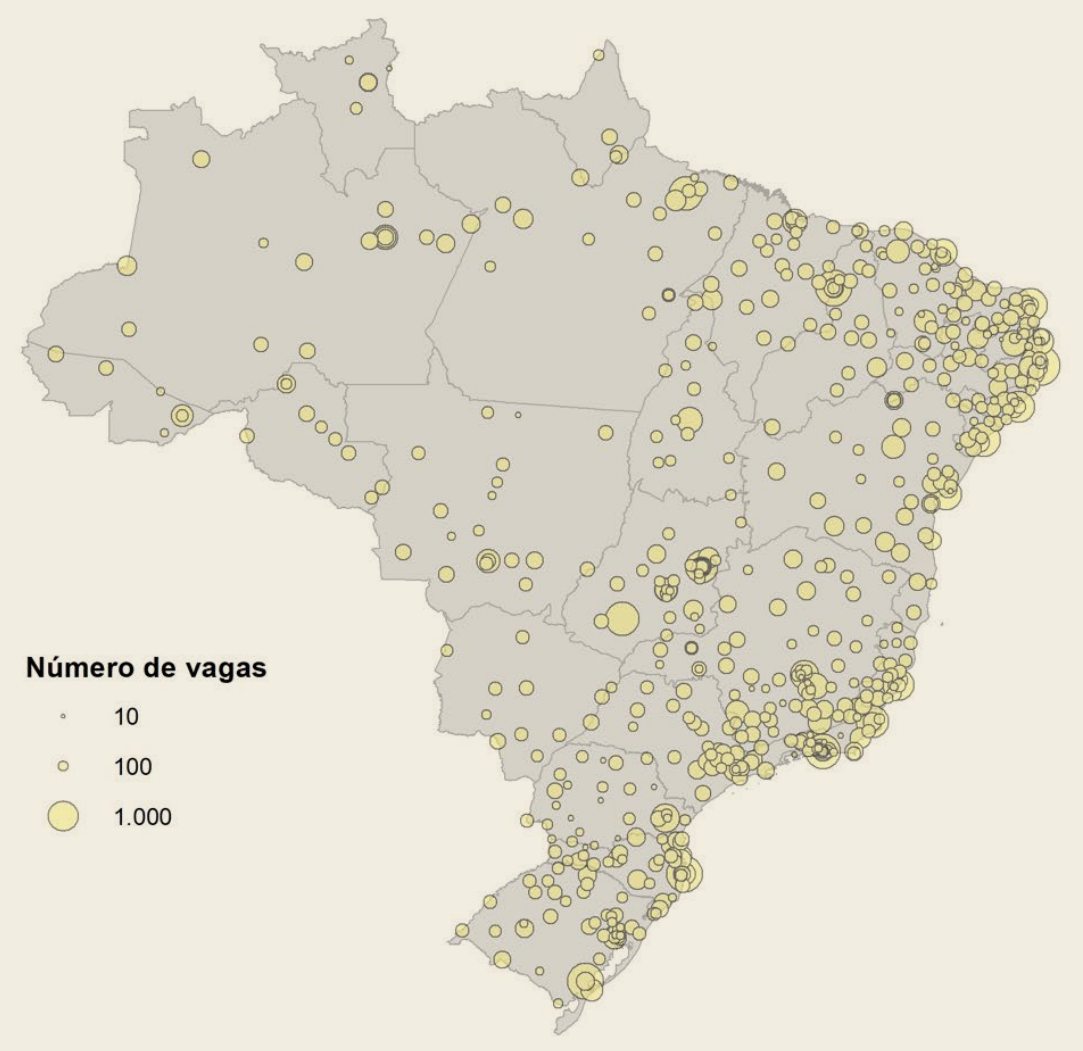

Fonte: Brasil (2019b) e Brasil (2021a). 


\section{DISCUSSÃO DE RESULTADOS}

O problema motivador deste trabalho relaciona-se à revisão crítica dos critérios de admissão dados por meio de provas com questões de múltipla escolha, que incentivam mais as capacidades cognitivas de memorização do que outros aspectos humanos, como o político, o social, o cultural e o estético. O problema é acentuado quando as próprias instituições escolares são fundadas em pressupostos teóricos que concebem a formação escolar de maneira omnilateral e não fragmentada. A Tabela 1 revela de maneira inequívoca a incongruência entre a concepção institucional da Rede Federal e os modelos de seleção de estudantes. Verifica-se que 91,8\% (550) das unidades de ensino de EMI utilizam apenas um tipo de processo seletivo. A maioria $(56,8 \%)$ das 599 unidades adotou o exame vestibular com questões de múltipla escolha.

Esse tipo de processo seletivo é justificado pela percepção subjetiva de equidade no tratamento e pela percepção objetiva de eficiência, já que o tempo de correção e publicação de resultados depende da capacidade tecnológica da banca organizadora do certame. Por outro lado, os custos desse processo são altos e não há garantia de que os admitidos são vocacionados ao curso técnico, uma vez que a prova apresenta conteúdos pontuais, fragmentados e sem relação com as habilidades da área técnica pretendida. A cultura do vestibular é reforçada desde o ensino fundamental, condicionando os admitidos na Rede Federal a buscarem uma formação sólida nas áreas científicas, com vistas à prova do Exame Nacional do Ensino Médio (Enem). Esse ciclo vicioso se estabeleceu no último quartel do século XX, quando os exames vestibulares substituíram os testes vocacionais, que consistiam em identificar certa tendência ou potencial orientador a partir de traços da personalidade dos ingressantes para adequá-los às exigências profissionais. As razões para essa substituição são variadas: a revogação da obrigatoriedade da qualificação profissional no nível médio, as dificuldades burocráticas de se realizar a orientação vocacional e as críticas à ênfase psicologista da escolha profissional (MELO-SILVA; MUNHOZ; LEAL, 2019). Na Rede Federal, a principal razão relaciona-se ao processo de “cefetização" ainda em vigor. Os únicos institutos que ainda mantêm testes de aptidão são aqueles que ofertam cursos na área de música, no campus Teresina Central (Instituto Federal do Piauí - IFPI), em Goiânia (Instituto Federal de Goiás - IFG) e nos campi do Colégio Pedro II (RJ). Exige-se do candidato algum rudimento de técnica instrumental como critério de classificação em conjunto com o exame vestibular. Esse modelo poderia ser implementado sem grandes dificuldades em outros cursos técnicos, especialmente aqueles com os quais os estudantes pouco se identificam. Ferreira, Raitz e Vanzuita (2016) indicam a falta de aderência entre a formação técnica e os interesses profissionais dos estudantes com dados sobre o acompanhamento de egressos no Instituto Federal Catarinense (IFC). 
O problema das avaliações de múltipla escolha se torna ainda mais relevante ao examinarmos mais detidamente sua inconsistência com a concepção integrada de ensino, que vinculou historicamente, como vimos no item do referencial teórico, as habilidades técnico-profissionalizantes às competências do núcleo pedagógico-científico comum. Os processos seletivos passaram a contemplar, em sua grande parte, conhecimentos teóricos básicos do ensino fundamental. Cunha (2005b) e Kuenzer (2011) explicam-no por meio da análise da manutenção histórica da dualidade fundante da educação brasileira, de que os processos seletivos são uma expressão.

$\mathrm{O}$ acréscimo da redação à prova de múltipla escolha, modelo adotado no sul de Minas Gerais, no Paraná e no Rio Grande do Norte, abrange a avaliação de competências de ordem verbo-linguística. Nesses casos, exige-se um texto "dissertativo-expositivo" (Instituto Federal do Sul de Minas Gerais - IFSULDEMINAS), "dissertativo-argumentativo" (Instituto Federal do Paraná - IFPR) ou um "artigo de opinião" (Instituto Federal do Rio Grande do Norte - IFRN), nos moldes do Enem, sobre um tema de impacto social e com a oferta de textos motivadores. Por motivos demográficos e geográficos, o campus São Gabriel da Cachoeira (Instituto Federal do Amazonas - IFAM), localizado no extremo norte do país, também adotou esse modelo de seleção. A administração municipal foi descentralizada e a gestão escolar modificou a forma de exame para atender as comunidades do campo e indígenas do entorno, as quais teriam dificuldades de acesso para realizar a matrícula e retornar à sede do município para prestar o exame. A instituição concentrou todo o processo em um dia e aceitou que a redação fosse redigida em língua portuguesa ou nas línguas indígenas cooficiais do Alto Rio Negro (baniwa, nheengatu, tukano, yanomami).

O Centro Federal de Educação Tecnológica do Rio de Janeiro (Cefet-RJ) continua a emular os antigos vestibulares de Universidades tradicionais, dividindo o processo seletivo em duas fases: uma prova de múltipla escolha (Português, Matemática, Ciências e Estudos Sociais) classifica os candidatos à fase contendo uma redação e uma prova discursiva de Matemática. Na maior parte dos casos, cobra-se uma taxa de inscrição como forma de diminuir os custos do processo seletivo, concedendo-se isenções conforme o perfil socioeconômico. No caso do Cefet-RJ, a taxa foi de $\mathrm{R} \$ 75,00$. Esse modelo resolve, com alto custo financeiro, a variável "sorte", muitas vezes decisiva em processos com baixa relação entre candidatos e vagas.

O segundo tipo de processo mais prevalente é a análise de currículo, adotado por cerca de $1 / 4$ do total de unidades. Avaliam-se as notas constantes no histórico escolar do ensino fundamental. A rigor, todas as instituições utilizam esse processo, na medida em que a Lei n. 12.711 (BRASIL, 2012), a Lei de Cotas, reserva metade das vagas pelo critério de origem escolar. A diferença é que a análise de histórico envolve o cômputo das notas de algumas disciplinas dos anos finais do ensino fundamental, 
com prevalência para o $7^{\circ}$ e $8^{\circ}$ anos e para as disciplinas de Matemática e Português. No IFAM, avaliam-se as notas de Ciências. O Instituto Federal Farroupilha acrescenta Geografia e História. A maior parte das instituições considera as notas do $7^{\circ}$ e $8^{\circ}$ anos. Fogem à regra os campi Amajari e Novo Paraíso (Instituto Federal de Roraima - IFRR), que consideram as notas do $6^{\circ}$ ao $9^{\circ}$ ano (parciais). Vale mencionar que nenhuma análise de histórico considera as notas de disciplinas obrigatórias do ensino fundamental tais como Educação Física, Artes e Inglês.

O sorteio é a forma de admissão nos 11 campi do Instituto Federal de Brasília (IFB) e em quatro campi do Instituto Federal de Santa Catarina (IFSC), previsto em edital quando o número de inscritos for menor que o de candidatos. Outras instituições podem adotar esse procedimento após as chamadas da lista de aprovados ou realizar chamamento público para preencher as vagas remanescentes. O sorteio e a chamada pública não representavam mais do que 5\% dos tipos de processo seletivo adotados. Num modelo societal meritocrático, as vantagens do sorteio e do chamamento, a saber, ter baixo custo de execução e oportunizar um ensino de qualidade a todos de modo igualitário, são dirimidas pela percepção de injustiça em relação ao mérito dos candidatos.

A autonomia pedagógica das instituições de ensino permite aos gestores das unidades da Rede Federal adotarem modelos mistos ou processos seletivos próprios para cada curso técnico ofertado. A Figura 2-B mostra as unidades com mais de um tipo de processo seletivo. Ressaltam-se dois campi do IFNMG: em Araçuaí há cursos que selecionaram estudantes por meio de análise de currículo e cursos que mantiveram o vestibular. Em Almenara, o curso técnico de Agropecuária em regime de alternância foi o único do país a ao mesmo tempo realizar entrevistas e analisar o histórico escolar dos candidatos. As razões para essa distinção podem estar relacionadas ao perfil rural do curso e do campus, e ao perfil socioeconômico dos egressos, já que o regime em alternância exige a aplicação dos conteúdos na comunidade agrária local, sendo a entrevista um modo de confirmar a adequação entre os perfis.

A combinação de duas ou três modalidades de seleção é mais adequada aos princípios de formação omnilateral da Rede Federal. É importante que os gestores e a comunidade acadêmica realizem estudos para identificar a melhor forma de seleção para os cursos, de acordo com o perfil do egresso e com os arranjos produtivos profissionais e socioculturais. A Figura 2-C permite a visualização da concentração de oferta de vagas no litoral do Brasil. Oito dos dez campi com maior oferta localizam-se no litoral. Em termos absolutos, o campus Recife é o que mais ofertou vagas em 2019 (1.762). Por outro lado, o campus avançado de Soledade (IFPB) foi o que ofereceu menos, apenas trinta vagas de EMI. O processo de interiorização da Rede Federal está longe de se efetivar. Apesar disso, modelos inovadores como os de Almenara (região do Vale do Jequitinhonha-MG) e São Gabriel da Cachoeira (região da Amazônia-AM), 
distantes dos grandes centros urbanos, puderam estabelecer processos seletivos em conformidade com o seu contexto social.

\section{CONSIDERAÇÕES FINAIS}

Os índices de avaliação de eficiência das Instituições Federais de Educação Tecnológica são mais abrangentes do que os índices relativos à gestão das Instituições Federais de Ensino Superior. O Acórdão TCU n. 2.267 (BRASIL, 2005a) propôs os índices para avaliar o desempenho da gestão das instituições federais de ensino em três eixos: acadêmico, administrativo e socioeconômico (PRATES, 2018). Ainda assim, existem poucos estudos sistemáticos sobre a eficiência acadêmica em relação à gestão da Rede Federal. Neste artigo, que cobriu uma pequena parte dessa lacuna ao identificar e analisar os tipos de processo de admissão de estudantes na Rede Federal de Educação Tecnológica no Brasil, objetivou-se fundamentar as políticas públicas e a ação de gestores para propostas de processos seletivos mais adequados para cada contexto educacional. De acordo com o tipo de proposta pedagógica e com o perfil do egresso que se pretende formar, as variáveis de acesso relevantes, conforme evidenciadas nesta pesquisa, podem ser selecionadas, permitindo a formulação de um processo de admissão específico para cada comunidade escolar. Esse tipo de análise poderá fomentar outras pesquisas que incluam, em seguida, os dados de admissão nos planos de permanência e êxito das instituições de ensino da Rede Federal. Outras questões relacionadas que podem ensejar novas pesquisas são as seguintes: a relação entre inscritos no processo seletivo e as vagas ofertadas é relevante para a implementação de um tipo de admissão em detrimento de outro? As taxas de evasão, retenção e a eficiência acadêmica estão relacionadas à forma de ingresso? Qual a medida para justificar os gastos com os processos seletivos?

Tais como as cotas, as remodelagens dos processos seletivos podem ser compreendidas como ações compensatórias e de inclusão social com potencial, inclusive, para melhor atender aos arranjos produtivos locais. Além disso, a confecção de um currículo planejado para reunir os conhecimentos do ensino médio às competências da educação profissional deve exigir um processo seletivo diferente daquele constituído de avaliações nas áreas de Língua Portuguesa e Matemática, que privilegiam conteúdos de disciplinas tradicionais do ensino fundamental, pouco compatíveis com o perfil profissional dos egressos almejado por aquelas instituições. Em virtude da necessidade de distanciamento social e da pandemia de covid-19, as instituições de ensino da Rede Federal foram obrigadas a alterar os seus métodos de seleção, adotando preferencialmente o sorteio e a análise de histórico escolar. Espera-se que os resultados desta pesquisa possam motivar a intervenção nas práticas de processos seletivos das instituições com currículos profissionais integrados 


\section{ao ensino médio, não apenas por obrigação momentânea, mas por cumprir os pro- pósitos de eficiência e inclusão escolar.}

\section{REFERÊNCIAS}

AMORIM, Mônica. A organização dos Institutos Federais de Educação, Ciência e Tecnologia no conjunto da educação profissional brasileira. 2013. 245 f. Tese (Doutorado em Educação) - Faculdade de Educação, Universidade Federal de Minas Gerais, Belo Horizonte, 2013.

BOURDIEU, Pierre; PASSERON, Jean Claude. A reprodução: elementos para uma teoria do sistema de ensino. 3. ed. Rio de Janeiro: Francisco Alves, 1992.

BRANDÃO, Marisa. Da arte do ofício à ciência da indústria: a conformação do capitalismo industrial no Brasil vista através da Educação Profissional. Boletim Técnico do SENAC, Rio de Janeiro, v. 25, n. 3, p. 17-30, set./dez. 1999.

BRASIL. Decreto n. 7.566, de 23 de setembro de 1909. Crêa nas capitaes dos Estados da Republica Escolas de Aprendizes Artifices, para o ensino profissional primario e gratuito. Diário Official, Rio de Janeiro, p. 6975, 26 set. 1909.

BRASIL. Decreto-lei n. 4.078, de 2 de fevereiro de 1942. Concede pensões aos herdeiros legais dos cabos e soldados do Corpo de Bombeiros do D. Federal, falecidos em consequência de acidentes em serviço. Diário Oficial da União: Seção 1, Rio de Janeiro, p. 1767, 4 fev. 1942a.

BRASIL. Decreto-lei n. 4.244, de 9 de abril de 1942. Lei orgânica do ensino secundário. Diário Oficial da União: Seção 1, Rio de Janeiro, p. 5798, 10 abr. 1942b.

BRASIL. Lei n. 1.076, de 31 de março de 1950. Assegura aos estudantes que concluírem curso de primeiro ciclo do ensino comercial, industrial ou agrícola, o direito à matrícula nos cursos clássico e científico e dá outras providências. Diário Oficial da União: Seção 1, Rio de Janeiro, p. 5425, 12 abr. 1950.

BRASIL. Decreto n. 34.330, de 21 de outubro de 1953. Regulamenta a Lei n. 1.821, de 12 de março de 1953. Diário Oficial da União: Seção 1, Rio de Janeiro, p. 18590, 3 nov. 1953.

BRASIL. Lei n. 3.552, de 16 de fevereiro de 1959. Dispõe sobre nova organização escolar e administrativa dos estabelecimentos de ensino industrial do Ministério da Educação e Cultura, e dá outras providências. Diário Oficial da União: Seção 1, Rio de Janeiro, p. 3009, 17 fev. 1959.

BRASIL. Lei n. 4.024, de 20 de dezembro de 1961. Fixa as Diretrizes e Bases da Educação Nacional. Diário Oficial da União: Seção 1, Brasília, 27 dez. 1961.

BRASIL. Decreto n. 53.041, de 28 de novembro de 1963. Atribui ao Grupo de Trabalho de Expansão do Ensino Industrial os serviços técnicos que vem sendo realizados, pela Comissão Brasileiro-Americana de Educação Industrial e dá outras providências. Diário Oficial da União: Seção 1, Brasília, p. 10224, 5 dez. 1963.

BRASIL. Lei n. 5.692, de 11 de agosto de 1971. Fixa Diretrizes e Bases para o ensino de $1^{\circ}$ e $2^{\circ}$ graus, e dá outras providências. Diário Oficial da União: Seção 1, Brasília, p. 6377, 12 ago. 1971. 
BRASIL. Lei n. 6.545, de 30 de junho de 1978. Dispõe sobre a transformação das Escolas Técnicas Federais de Minas Gerais, do Paraná e Celso Suckow da Fonseca em Centros Federais de Educação Tecnológica e dá outras providências. Diário Oficial da União: Seção 1, Brasília, p. 10233, 4 jul. 1978.

BRASIL. Constituição da República Federativa do Brasil de 1988. Diário Oficial da União: Seção 1, Brasília, p. 1, 5 out. 1988.

BRASIL. Lei n. 8.948, de 8 de dezembro de 1994. Dispõe sobre a instituição do Sistema Nacional de Educação Tecnológica e dá outras providências. Diário Oficial da União: Seção 1, Brasília, p. 18882, 9 dez. 1994.

BRASIL. Lei n. 9.394, de 20 de dezembro de 1996. Estabelece as Diretrizes e Bases da Educação Nacional. Diário Oficial da União: Seção 1, Brasília, p. 27833, 23 dez. 1996.

BRASIL. Decreto n. 2.208, de 17 de abril de 1997. Regulamenta o $\S 2^{\circ}$ do art. 36 e os artigos 39 a 42 da Lei n. 9.394, de 20 de dezembro de 1996, que estabelece as diretrizes e bases da educação nacional. Diário Oficial da União: Seção 1, Brasília, p. 7760, 18 abr. 1997a.

BRASIL. Decreto n. 2.406, de 27 de novembro de 1997. Regulamenta a Lei n. 8.948, de 8 de dezembro de 1994, e dá outras providências. Diário Oficial da União: Seção 1, Brasília, p. 27937, 28 nov. 1997b.

BRASIL. Tribunal de Contas da União. Acórdão n. 2.267, de 13 de dezembro de 2005. Auditoria no Programa de Educação Profissional - Proep, a cargo da Secretaria de Educação Profissional e Tecnológica - Setec/MEC e das Instituições Federais de Educação Tecnológica - IFETS. Brasília, 2005a. Disponível em: https://pesquisa.apps.tcu.gov.br/\#/redireciona/acordaocompleto/\%22ACORDAO-COMPLETO-26325\%22. Acesso em: 10 nov. 2021.

BRASIL. Decreto n. 5.478, de 24 de junho de 2005. Institui, no âmbito das instituições federais de educação tecnológica, o Programa de Integração da Educação Profissional ao Ensino Médio na Modalidade de Educação de Jovens e Adultos - Proeja. Diário Oficial da União: Seção 1, Brasília, p. 4, 27 jun. 2005b.

BRASIL. Lei n. 11.892, de 29 de dezembro de 2008. Institui a Rede Federal de Educação Profissional, Científica e Tecnológica, cria os Institutos Federais de Educação, Ciência e Tecnologia, e dá outras providências. Diário Oficial da União: Edição Extra, Brasília, p. 1, 30 dez. 2008.

BRASIL. Ministério da Educação. Centenário da Rede Federal de Educação Profissional e Tecnológica. Brasília, 2009. Disponível em: http://portal.mec.gov.br/setec/arquivos/centenario/historico_ educacao_profissional.pdf. Acesso em: 10 nov. 2021.

BRASIL. Lei n. 12.711, de 29 de agosto de 2012. Dispõe sobre o ingresso nas universidades federais e nas instituições federais de ensino técnico de nível médio e dá outras providências. Diário Oficial da União: Seção 1, Brasília, p. 1, 30 ago. 2012.

BRASIL. Decreto n. 9.741, de 29 de março de 2019. Altera o Decreto n. 9.711, de 15 de fevereiro de 2019, que dispõe sobre a programação orçamentária e financeira, estabelece o cronograma mensal de desembolso do Poder Executivo federal para o exercício de 2019 e dá outras providências. Diário Oficial da União: Edição Extra, Brasília, p. 1, 29 mar. 2019a.

BRASIL. Ministério da Educação. Plataforma Nilo Peçanha (comp.). Brasília: Rede Federal de Educação Profissional, Científica e Tecnológica Setec/MEC: PNP, 2019b. Disponível em: http:// plataformanilopecanha.mec.gov.br/2019.html. Acesso em: 21 out. 2019. 
BRASIL. Lei Complementar n. 173, de 27 de maio de 2020. Estabelece o Programa Federativo de Enfrentamento ao Coronavírus SARS-CoV-2 (Covid-19), altera a Lei Complementar n. 101, de 4 de maio de 2000, e dá outras providências. Diário Oficial da União: Seção 1, Brasília, p. 4, 27 maio 2020.

BRASIL. Controladoria-Geral da União. FALA.BR: Plataforma Integrada de Ouvidoria e Acesso à Informação. Brasília, 2021a. Disponível em: https://falabr.cgu.gov.br/publico/Manifestacao/ SelecionarTipoManifestacao.aspx?ReturnUrl=\%2f. Acesso em: 10 nov. 2021.

BRASIL. Instituto Nacional de Estudos e Pesquisas Educacionais Anísio Teixeira. Censo da Educação Básica 2020: resumo técnico. Brasília: Inep, 2021b.

CAMPELLO, Ana Margarida. "Cefetização” das Escolas Técnicas Federais: projetos em disputa, nos anos 1970 e 1990. Educação \& Tecnologia, Belo Horizonte, v. 12, n. 1, p. 26-35, jan./abr. 2007.

COUTINHO, Eduardo; MELO, Frederico de. Inovações socioeducacionais e os processos seletivos dos cursos técnicos da Rede Federal de Educação Profissional e Tecnológica. Educação \& Tecnologia, Belo Horizonte, v. 15, n. 3, p. 22-35, set./dez. 2010.

CUNHA, Antônio Luiz. O ensino de ofícios artesanais e manufatureiros no Brasil escravocrata. 2. ed. São Paulo; Brasília: Editora da Unesp; Flacso, 2005a.

CUNHA, Antônio Luiz. O ensino de ofícios nos primórdios da industrialização. 2. ed. São Paulo; Brasília: Editora da Unesp; Flacso, 2005b.

CUNHA, Antônio Luiz. O ensino profissional na irradiação do industrialismo. 2. ed. São Paulo; Brasília: Editora da Unesp; Flacso, 2005c.

FERREIRA, Danilo José; RAITZ, Tania Regina; VANZUITA, Alexandre. As trajetórias dos egressos do ensino médio integrado em agropecuária: rumo ao trabalho ou ensino superior? Boletim Técnico do Senac, Rio de Janeiro, v. 42, n. 3, p. 54-75, set./dez. 2016.

FONSECA, Celso Suckow da. História do ensino industrial no Brasil. Rio de Janeiro: MEC, 1961. v. 1.

FONSECA, Celso Suckow da. História do ensino industrial no Brasil. Rio de Janeiro: MEC, 1962. v. 2.

HAJ, Cezar Mihai; GEANTA, Irina Mihaela; ORR, Dominic. A typology of admission systems across Europe and their impact on the equity of access, progression and completion in higher education. In: CURAJ, Adrian; DECA, Ligia; PRICOPIE, Remus (ed.). European higher education area: the impact of past and future policies. Cham: Springer, 2018. p. 171-187. Disponível em: https://link.springer.com/chapter/10.1007/978-3-319-77407-7_12. Acesso em: 21 out. 2019.

KUENZER, Acacia. EM e EP na produção flexível: a dualidade invertida. Revista Retratos da Escola, Brasília, v. 5, n. 8, p. 43-55, jan./jun. 2011.

MELO-SILVA, Lucy; MUNHOZ, Izildinha; LEAL, Mara. Orientação profissional na educação básica como política pública no Brasil. Revista Brasileira de Orientação Profissional, São Paulo, v. 20, n. 1, p. 3-18, jan./jun. 2019.

PACHECO, Eliezer. Os Institutos Federais: uma revolução na educação profissional e tecnológica. Natal: IFRN, 2010.

PACHECO, Eliezer. Perspectivas da educação profissional técnica de nivel médio: proposta de Diretrizes Curriculares Nacionais. Brasília; São Paulo: Setec-MEC; Moderna, 2014. 
PACHECO, Eliezer. Desvendando os Institutos Federais: identidade e objetivos. Educação Profissional e Tecnológica em Revista, Vitória, v. 4, n. 1, p. 3-22, abr. 2020.

PACHECO, Eliezer; PEREIRA, Luiz Augusto; DOMINGOS SOBRINHO, Moisés. Educação profissional e tecnológica: das Escolas de Aprendizes Artífices aos Institutos Federais de Educação, Ciência e Tecnologia. T\&C Amazônia, Manaus, v. 7, n. 16, p. 2-7, fev. 2009.

PORTO JUNIOR, Manoel José; DEL PINO, Mauro; AMARAL, Giana do. A exclusão escolar no CefetRS: do curso integrado ao curso modular. Trabalho e Educação, Belo Horizonte, v. 18, n. 1, p. 89-105, jan./abr. 2009.

PRATES, Caroline Leal. Avaliação de eficiência em instituições de ensino público: um estudo nas unidades do Instituto Federal do Rio Grande do Sul. 2018. 104 f. Dissertação (Mestrado em Engenharia de Produção) - Universidade de Caxias do Sul, Bento Gonçalves, RS, 2018.

SAVIANI, Dermeval. Pedagogia histórico-crítica. 6. ed. Campinas, SP: Autores Associados, 1997.

SCHWARTZMAN, Simon. O Centro Paula Souza e a Educação Profissional no Brasil. In: NEGRI, Barjas; TORRES, Haroldo da Gama; CASTRO, Maria Helena Guimarães de (org.). Educação Básica no Estado de São Paulo: avanços e desafios. São Paulo: Fundação Seade, 2014. p. 187-216. Disponível em: https://archive.org/details/simon_seade_capa. Acesso em: 5 fev. 2021.

SILVA, Maria das Graças; VELOSO, Tereza Christina. Acesso nas políticas da educação superior: dimensões e indicadores em questão. Avaliação: Revista da Avaliação da Educação Superior, Campinas; Sorocaba, SP, v. 18, n. 3, p. 727-747, nov. 2013.

WACHOWICZ, Lílian. Avaliação da aprendizagem profissional. Curitiba: IFPR, 2014.

\section{COMO CITAR ESTE ARTIGO}

MARTINS, Alex Lara; COSTA, Alfredo. Formas de ingresso nos cursos técnicos de nível médio da Rede Federal de Ensino. Estudos em Avaliação Educacional, São Paulo, v. 32, e08516, 2021.

DOI: https://doi.org/10.18222/eae.v32.8516

Recebido em: 29 MARÇO 2021

Aprovado para publicação em: 24 AGOSTO 2021 